\title{
Assessment of Sustainable Use of Coastal Resources of Regional Waters Conservation Area Biak Numfor Regency, Papua Province, Indonesia
}

\author{
Sutaman ${ }^{1 *}$, Yusli Wardiatno², Mennofatria Boer ${ }^{2}$ and Fredinan Yulianda² \\ ${ }^{1}$ Post Graduated School on Marine and Coastal Resources Management, Bogor Agricultural University, Academic \\ Ring Road, Campus IPB Dramaga, PO BOX 168, Bogor, 16680, Indonesia \\ 2Department of Waters Resources Management, Faculty of Fisheries and Marine Science, Bogor Agricultural \\ University, Academic Ring Road, Campus IPB Dramaga, PO BOX 168, Bogor, 16680 \\ Email: sutaman@gmail.com
}

\begin{abstract}
Utilization of fishery resources in an optimal, continous and sustainable manner is an urgent demand for the prosperity of the people, especially to improve the welfare of fishermen and coastal communities. The level of sustainable use of coastal resources in water conservation is very important, so that the utilization does not exceed the carrying capacity of the environment. The purpose of this study was to determine the level of sustainable use of coastal resources Biak Numfor, associated with the utilization of fisheries, aquaculture and tourism. The study was conducted in June to December 2015 and October to November 2016. The primary data obtained by interview and direct discussion through Focus Group Disscution (FGD) with fishermen community, tourist and tourist entrepreneurs as well as related officials in the Office of Fisheries and Marine Affairs, and Tourism Office of Biak Numfor Regency. Methods of data analysis approach sustainability analysis conducted by the method of MDS (Multi-Dimensional Scaling) with the help of software Rapfish. Based on the survey results revealed that the value of fisheries ordinated to achieve $57.66 \%, 44.80 \%$ aquaculture, and tourism $46.25 \%$. With these achievements ordinated value, it can be concluded that the use of sustainable capture fisheries are still classified by the lever sustainability attributes include; the type of fishing gear, vessel types used and the catch per unit effort (CPUE). Meanwhile the relatively less sustainable aquaculture with the sustainability lever attributes include; cultivation technology, the number of business units with different types and species of fish. For tourism utilization is still considered less sustainable with levers sustainability attributes include the number of tourists, the type and number of amenities and facilities and infrastructure
\end{abstract}

Keywords: Sustainability, utilization, waters conservation area (KKPD), MDS-Rapfish

\section{Introduction}

Efforts to utilize fish resources optimally, sustainably and sustainably is a very urgent demand for the greatest amount of prosperity of the people, especially to improve the welfare of fishermen and fish farmers. Based on this, in order to provide maximum benefits for the people and the state of Indonesia and ensure the sustainability of fishery business itself, it should be the development and national fishery activities as soon as possible directed to apply the rules of sustainable fisheries. Gombos et al. (2013) argues that over-exploitation of coastal and marine resources is extremely dangerous in the sustainable use of resources, while accelerating the loss of biodiversity and ecosystem stability. Adam (2012) states that the exploitation of fishery resources should not be done destructively, and should consider sustainable use
The sustainable use of coastal and marine resources especially capture, cultivation and tourism become very important in a management effort. Efforts to utilize coastal resources optimally, sustainably and sustainably is a very urgent demands for the great-prosperity of the people, especially to improve the welfare of fishermen and fish farmers. Based on Itam et al. (2014) small-scale fisheries in developing countries make important contributions to nutrition, food security, sustainable livelihoods and poverty alleviation. Potential utilization of coastal and marine resources, not only in the fishery sector, but also in other economic sectors such as tourism, marine transportation and renewable energy. Currently the utilization of coastal and marine resources especially in conservation areas is still very limited. Tajerin et al. (2010) found that in general the position of linkage of marine and fishery sub-sector with other sectors in Indonesian economy is included 
in potential groups and less developed groups. Furthermore, according to Yusvianty (2010), along with the depletion of natural resources in the mainland and the abundance of coastal resources and oceans owned by Indonesia become one of consideration with the paradigm shift toward the maritime state from the original terrestrial state. This is one reason for the importance of development in the field of marine and fisheries.

The existence of regional waters conservation area Biak Numfor actually play a very important role for the preservation of marine resources in the coastal region. But the area has also been used for various economic activities, and is a source of livelihood for most communities around the coastal area. Resource sustainability analysis can provide input and consideration for Local Government in developing, managing and utilizing fishery resources and maritime tourism in Biak Numfor watershed conservation area in a sustainable manner. Therefore, the purpose of this study is to determine the level of sustainability of resource utilization of Biak Numfor Regency related to the utilization of capture fishery, aquaculture fishery and tourism. This data was obtained by interview and direct discussion through Focus Group Disscution (FGD) with fishermen community, tourist and tourist entrepreneurs as well as related officials in the Office of Fisheries and Marine Affairs, and Tourism Office of Biak Numfor Regency.

\section{Materials and Methods}

\section{Time and location}

The research was conducted in June to December 2015 and October to November 2016. This research was conducted in the waters conservation area (KKPD) Biak Numfor, which includes three (3) region, i.e. 1) KKPD Biak East Coast, 2) KKPD Biak West Coast and 3) KKPD Numfor Island (Figure 1). Location study include eight (8) districts included in the KKPD of the 19 districts in Biak Numfor regency.

\section{Type and source of data}

Types of data collected in the study of the sustainability level of resource utilization in regional waters conservation area (KKPD) Biak Numfor, consist of primary and secondary data. Primery data was obtained by interview and direct discussion through Focus Group Disscution (FGD) with fishermen community, tourist and tourist entrepreneurs as well as related officials in the Office of Fisheries and Marine Affairs, and Tourism Office of Biak Numfor Regency. While secondary data is data obtained from the relevant office in the form of reports, data and other information. Types and methods of data collection is done, in more detail in Table 1.

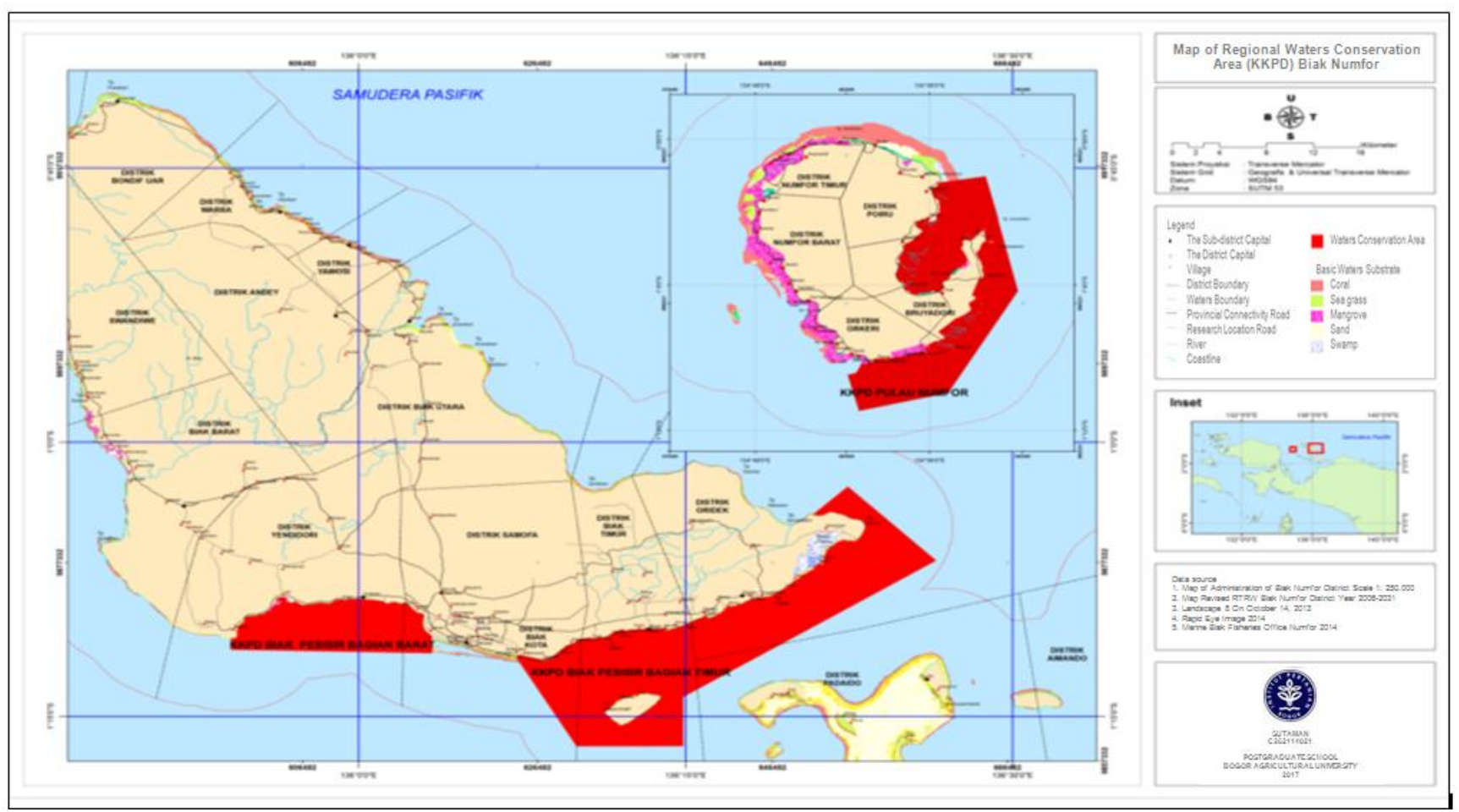

Figure 1. Map of Regional Waters Conservation Area (KKPD) Biak Numfor 
Table 1. Type and source of data

\begin{tabular}{|c|c|c|c|}
\hline Aspects & Variable & Type & Sources \\
\hline \multirow{12}{*}{$\begin{array}{l}\text { Capture } \\
\text { Fisheries }\end{array}$} & Potential of fish resources (capture fisheries) & Secondary data & MF Officer \\
\hline & Length capture (LC) & Primary data & Insitu \\
\hline & Harvest based on trophic group (trophic level) & Secondary data & MF Officer \\
\hline & Catch per unit effort (CPUE) & Secondary data & MF Officer \\
\hline & Maximum sustainable yiled (MSY) & Primary data & MF Officer \\
\hline & Type of fishing gear are allowed & Secondary data & MF Officer \\
\hline & Type of environmentally friendly fishing gear & Primary data & Observation \\
\hline & Vessel type are allowed & Secondary data & MF Officer \\
\hline & Operating method of fishing gear & Primary data & Observation \\
\hline & Potential conflicts on utilization of fisheries & Primary data & Observation \\
\hline & Technology's fisheries (fishing gear) & Primary data & Observation \\
\hline & Fishing equipments & Primary data & Observation \\
\hline \multirow{9}{*}{$\begin{array}{l}\text { Marine } \\
\text { Culture }\end{array}$} & Potential of marine culture & Secondary data & MF Officer \\
\hline & Amount of aquaculture businesses & Secondary data & MF Officer \\
\hline & Farmed fish species & Secondary data & MF Officer \\
\hline & Source of fish seed cultivation & Secondary data & MF Officer \\
\hline & Type of feed are allowed & Secondary data & MF Officer \\
\hline & Fish farming technology & Primary data & Observation \\
\hline & Amount of business units are allowed & Secondary data & MF Officer \\
\hline & Value of Net B/C & Primary data & Analysis \\
\hline & Social and cultural support for aquaculture & Primary data & Observation \\
\hline \multirow[t]{10}{*}{ Tourism } & Kinds of tourism & Secondary data & MF Officer \\
\hline & $\begin{array}{l}\text { The number of actors and the amount of effort that can be } \\
\text { allowed }\end{array}$ & Secondary data & MF Officer \\
\hline & $\begin{array}{l}\text { Opportunity for community engagement in marine tourism } \\
\text { activities }\end{array}$ & Secondary data & MF Officer \\
\hline & The number of tourists allowed per period of time/place & Secondary data & MF Officer \\
\hline & The type and amount of infrastructure that allowed & Secondary data & MF Officer \\
\hline & The number of vessels allowed in one place & Secondary data & MF Officer \\
\hline & Type and number of health facilities, and paramedics & Secondary data & MF Officer \\
\hline & Facilities and infrastructure supporting the tourism & Primary data & Observation \\
\hline & Institutional of tourism management & Primary data & Observation \\
\hline & Tourism information & Primary data & Observation \\
\hline
\end{tabular}

\section{Analysis method}

The data analysis method based research purposes, are to know of sustainability level of resource use (capture fishing, marine culture and tourism) in KKPD Biak Numfor. Methods of data analysis is conducted sustainability analysis approach by MDS method with Rapfish software. Rapfish (Rapid Appraisal for Fisheries), developed by Pitcher since 1999. This approach is based on the principle of Multi Criteria Analysis (MCA) by relying on an algorithm known as MDS algorithm (Herdiansyaah et al., 2014). Multi Dimensional
Scaling (MDS) is a method of computer-based statistical analysis techniques using the software Microsoft Excel or SPSS, which perform transformations on each dimension of sustainability. (Herdiansyah et al., 2014; Cahya, 2016; and Ratnaningtyas et al., 2016).

Indexing and status of sustainable use of coastal and marine resources KKPD Biak Numfor of each aspect and attributes, follows the concept developed by Pitcher since 1999 (Yusuf, 2016). Assessment scores every aspect represented by the worst scale (bad) 0\% up to the best (good) 100\%. 
Value index of $>50 \%$ can be stated that aspects of the examination have been sustained. Conversely, if the index value $<50 \%$ of these aspects have not been or are not sustainable. Category sustainability index presented in Table 2.

\section{Results and Discussion}

The results of sustainability analysis of resource use KKPD Biak Numfor covering the activities are capture fisheries, marine culture and tourism activities, obtained the value of sustainability ordination (MDS), Monte Carlo values and statistical values in Table 3.

Based Rapish analysis it was found that the results of the validation test Monte Carlo showed the difference very small is between $0.08 \%$ up to $0.68 \%$ or less than $1 \%$. These values indicate that error effect or the impact of a scoring error is relatively small. Thus, the model developed Rapfish, otherwise inadequate as probe index values of sustainability. According to Primawaty et al. (2013) and Herdiansyah et al. (2014) that the analysis of Monte Carlo simulation can be used as a method to evaluate the impact of random error in statistical analysis is done. The same thing also expressed Herdiansyah et al. (2014) that the Monte Carlo analysis can be an indicator of an error caused the provision of scoring in every attribute, variation of scoring in multidimensional for their opinions differ, the process of data analysis performed repeatedly, and errors in input data or data missing.

The results of goodness of fit also shows that the sustainability index prediction model can be used. Results obtained that value of Squared Correlation $\left(R^{2}\right)$ is between 0.9410 up to 0.9516 or close to 1 . The value of R-square is getting closer to 1 means data is mapped perfectly. The value

Table 2. Index of sustainable category

\begin{tabular}{cc}
\hline Value Index & Sustainability Categories \\
\hline $0-25$ & Bad; not Sustainable \\
$26-50$ & Less; Less Sustainable \\
$51-75$ & Enough; Sustainable enough \\
$76-100$ & Good; very Sustainable \\
\hline Sources: Pitcher(1999) &
\end{tabular}

illustrates that more than $90 \%$ can be explained by the model well, and the remaining $<10 \%$ are explained by factors/other attributes. Yusuf (2016) states that the value of Squared Correlation $\left(R^{2}\right)$ of more than $80 \%$ indicates that the prediction model sustainability index and adequate use.

In addition, the results of a lack of fit measure test or stress values obtained 0.1354 up to 0.1379 or close to 0 (nil). Stress value near nil, then the output produced more similar to the actual situation or the lower the stress, so that model is very better. Conversely, the high stress values show that model does not fit. Yusuf (2016) states that stress values can be tolerated is $<20 \%$. Thus the model can be received well.

\section{Capture fisheries sustainability}

Sustainable of fisheries use is describe the sustainability level of fisheries activities in the waters conservation area (KKPD) Biak Numfor (Figure 2).

Results of rapfish analysis for capture fisheries found that ordination value is $57.66 \%$ or classified as sustainable. Monte Carlo values is $56.99 \%$ which showed the difference is very small $(0.67 \%)$ or less than $1 \%$. These values indicate that error effect or the impact of a scoring error is relatively small. Thus, the rapfish model was developed, be avowed adequate as probe value sustainability index. According to Primawaty et al., (2013) and Herdiansyah et al. (2014), that the analysis of Monte Carlo simulation can be used as a method to evaluate the impact of random error in statistical analysis is done.

The ordination value is describe utilization conditions of resources is categorized as good (sustainable) on the side of capture fisheries. That is because, the activities of fishing is done by fisherman in core zone of KKPD Biak Numfor, generally using fisheries tools is traditional type, so that fish stocks around the region are very abundant. Besides, the public awareness to keep the waters conservation area also played a role to protecting the habitat of reef fish. Based on research

Table 3. Index of sustainability (MDS, Monte Carlo and Statistic values)

\begin{tabular}{|c|c|c|c|c|c|}
\hline \multirow{2}{*}{ Dimensions } & \multicolumn{2}{|c|}{ Sustainability Index (\%) } & \multirow{2}{*}{ Difference } & \multicolumn{2}{|c|}{ Statistic Values } \\
\hline & MDS & Monte Carlo & & $\mathrm{R}^{2}$ & Stress \\
\hline Capture fisheries & 57.66 & 56.99 & 0.67 & 0.9516 & 0.1363 \\
\hline Marine culture & 44.80 & 44.88 & 0.08 & 0.9410 & 0.1379 \\
\hline Tourism & 46.25 & 45.99 & 0.26 & 0.9467 & 0.1354 \\
\hline
\end{tabular}




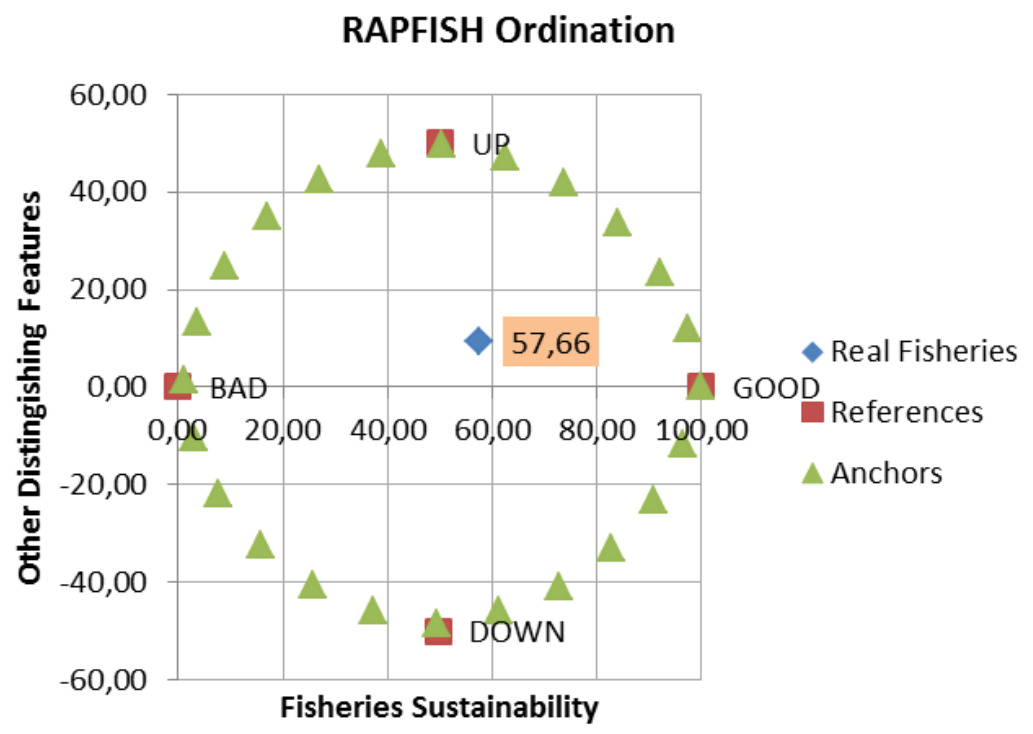

Figure 2. Graph ordinated sustainable of capture fisheries

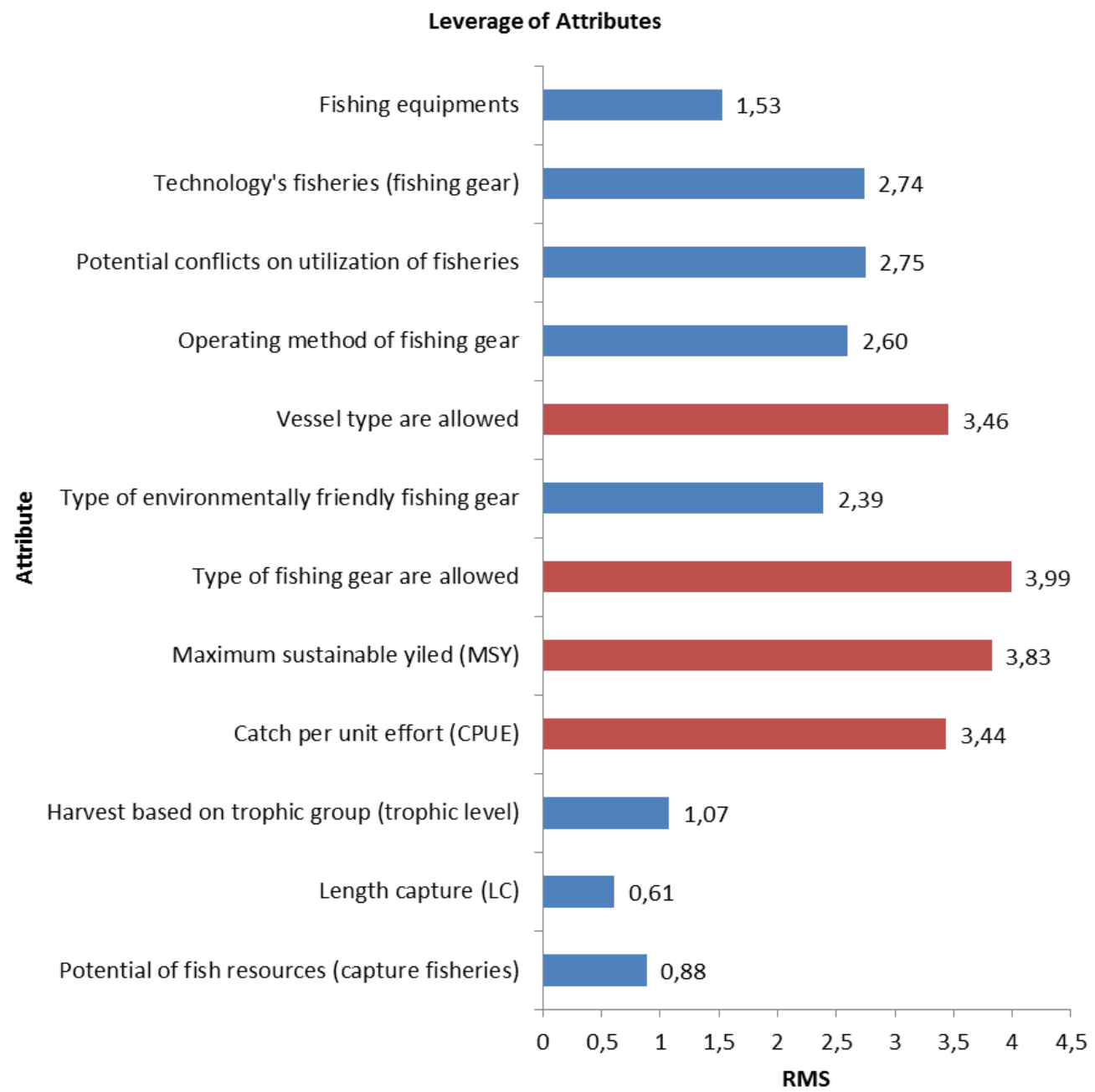

Figure 3. Graph leverage attribute of capture fishries sustainability 
Leleu et al. (2012), Reuchlin-Hugenholtz and McKenzie (2015) note that Marine Protected Areas (MPA) has beneficial effects on marine resources and the results when dealing with no-take zones (NTZs), artificial reefs and with regulations of over- fishing. Figure 3 is graph leverage atributte of capture fisheries.

Results of leverage analysis for capture fisheries obtained 4 (four) attribute which became

\section{RAPFISH Ordination}

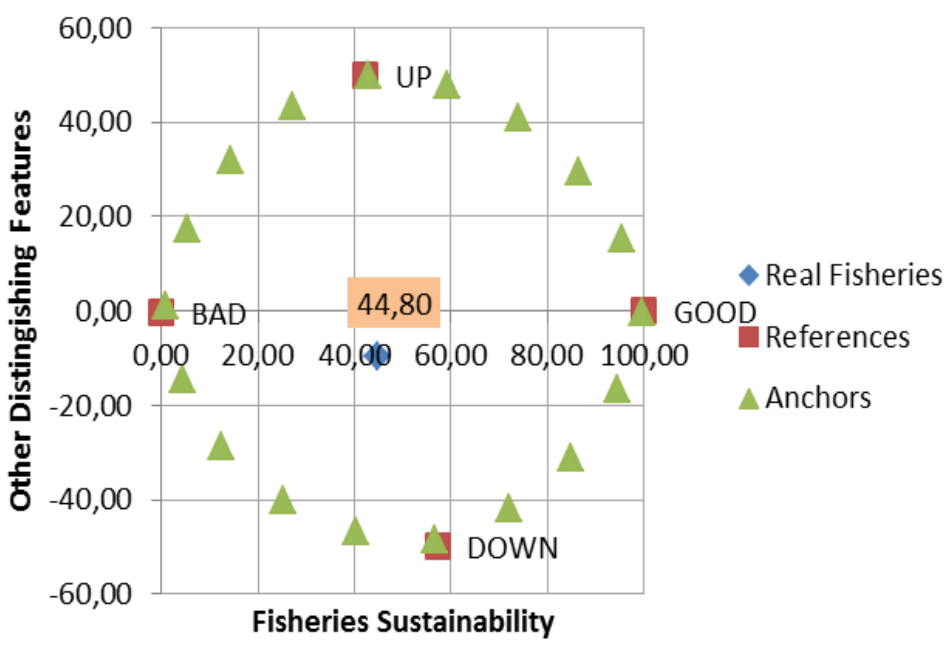

Figure 4. Graph ordinated sustainable of marine culture

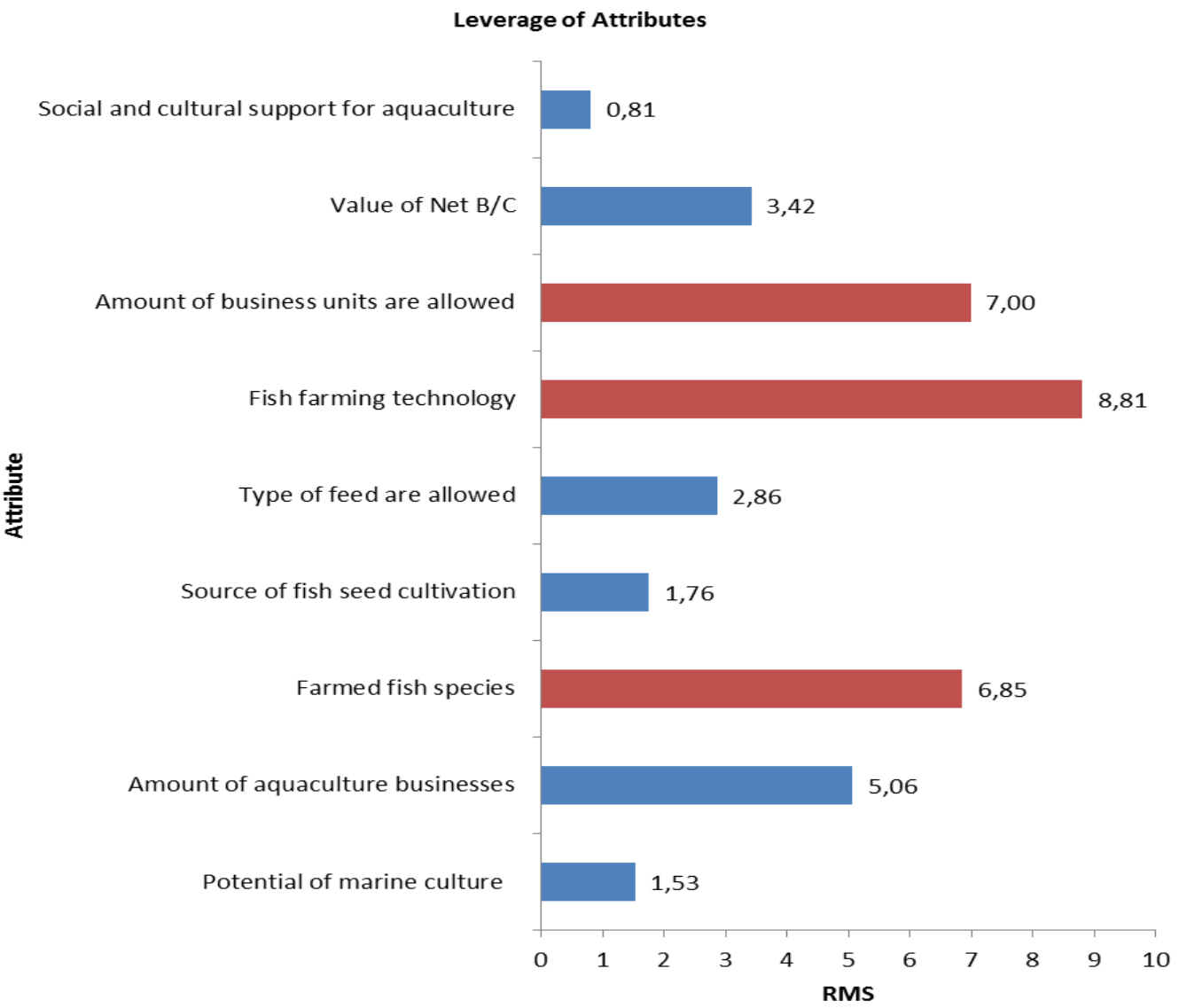

Figure 5. Graph leverage attribute of marine culture sustainability 
the most important indicators of sustainability from a variety of other attributes, i.e. type of fishing gear are allowed, maximum sustainable yield, vessel type are allowed and cacth per unit of effort.

These results indicate that all four of these attributes is a sensitive factor to supporting the sustainability of capture fisheries in KKPD Biak Numfor, so it should be a serious concern by government. Yusuf (2016) states that the RMS value indicates the magnitude of the role of each attribute to the sensitivity of sustainability status.

\section{Marine culture sustainability}

Marine culture sustainability is describe the sustainability level of fisheries activities, especially cultivation activities in the waters conservation area (KKPD) Biak Numfor (Figure 4).

Results of rapfish analysis for marine culture found that ordination value is $44.80 \%$ or classified as less sustainable. Monte Carlo values is $44.88 \%$ which showed the difference is very small $(0.08 \%)$ or less than $1 \%$. These values indicate that error effect or the impact of a scoring error is relatively small. Thus, the rapfish model was developed, be avowed adequate as probe value sustainability index. According to Primawaty et al., (2013) and Herdiansyah et al., 2014), that the analysis of Monte Carlo simulation can be used as a method to evaluate the impact of random error in statistical analysis is done.

The ordination value is describe utilization conditions of resources is categorized as bad (less sustainable) on the side of marine culture. That is because, the activities of cultivation in core zone of KKPD Biak Numfor is not managed well. The low sustainability of aquaculture due to very limited farming activities, both in the number of business units as well as the technological aspect of cultivation. it is because aquaculture is not an activity that is practiced by people in the region KKPD.

Results of leverage analysis for marine culture (Figure 5) obtained 3 (three) attribute which became the most important indicators of sustainability from a variety of other attributes, i.e. fish farming technology, amount of bussines unit are allowed, and farmed fish species.

These results indicate that all three of these attributes is a sensitive factor to supporting the sustainability of marine culture in KKPD Biak Numfor, so it should be a serious concern by government. Yusuf (2016) states that the RMS value indicates the magnitude of the role of each attribute to the sensitivity of sustainability status.

\section{Tourism sustainability}

Tourism sustainability is describe the sustainability level of using resource, especially tourism activities in the waters conservation area (KKPD) Biak Numfor (Figure 6).

Results of rapfish analysis for tourism found that ordination value is $46.25 \%$ or classified as less sustainable. Monte Carlo values is $45.99 \%$ which showed the difference is very small $(0.26 \%)$ or less

\section{RAPFISH Ordination}

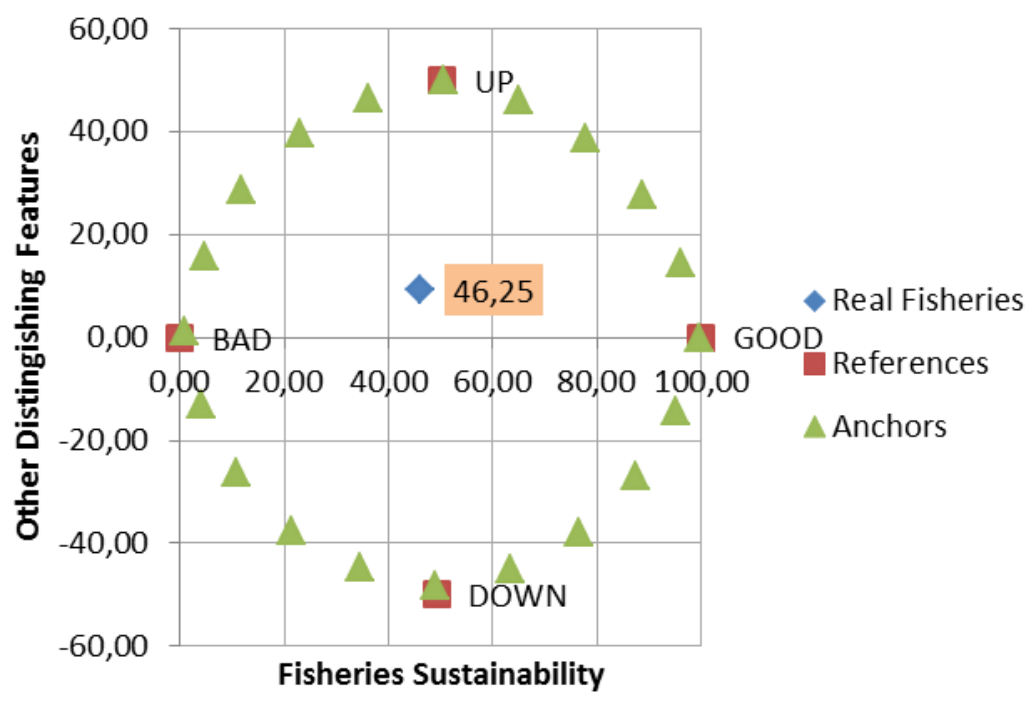

Figure 6. Graph ordinated sustainable of tourism 


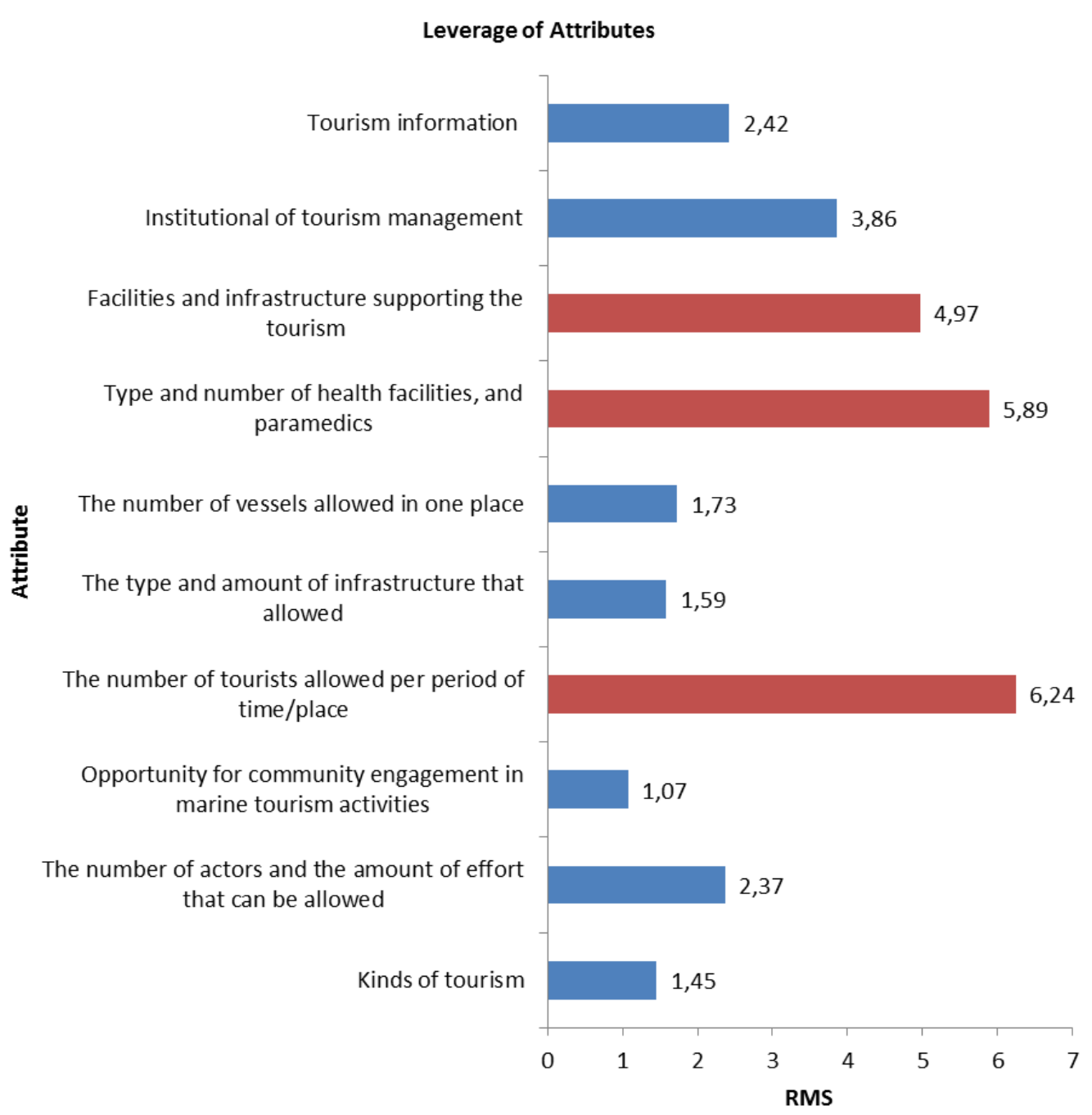

Figure 7. Graph leverage attribute of tourism sustainability

than $1 \%$. These values indicate that error effect or the impact of a scoring error is relatively small. Thus, the rapfish model was developed, be avowed adequate as probe value sustainability index. According to Primawaty et al., (2013) and Herdiansyah et al., 2014), that the analysis of Monte Carlo simulation can be used as a method to evaluate the impact of random error in statistical analysis is done.

The ordination value is describe utilization conditions of resources is categorized as bad (less sustainable) on the side of tourism. That is because, the activities of tourism in core zone of KKPD Biak Numfor is not managed well. Underwater scenery beautiful has not worked well, even still left naturally without optimal promotional efforts, so it has not attracted many foreign tourists to visit it. Hermantoro (2009), states that the sustainability of development based on the conservation of the natural environment has become an important part for tourism development, and is included in the concept of Suitainable tourism development supported by three pillars of economy, social culture and environment.

Results of leverage analysis for marine culture (Figure 7 ) obtained 3 (three) attribute which became the most important indicators of sustainability from a variety of other attributes, i.e. amount of tourism allowed per period of time/place, type and number of health facilities and paramedis and facilities and infrastructure supporting the tourism (Fauzi and Oxtavianus, 2014)

These results indicate that all three of these attributes is a sensitive factor to supporting the sustainability of tourism in KKPD Biak Numfor, so it should be a serious concern by government. Yusuf (2016) states that the RMS value indicates the 
magnitude of the role of each attribute to the sensitivity of sustainability status.

The analysis results show that the continuous utilization for tourism activities is still not sustainable, especially in relation to the number of tourists is still low, and the type of tourist facilities are still limited and supporting infrastructures are still inadequate.

\section{Conclusion}

Based on the result of the research, it can be concluded that the utilization of catch fishery is sustainable with ordination value reaching 57.66\%. While the use of aquaculture cultivation classified as less sustainable with ordination value only reached $44.80 \%$. The direction of tourism utilization is classified as less sustainable with $46.25 \%$ ordination value.

\section{Acknowledgment}

This research is funded from activities organized by the Office of Marine and Fisheries of Biak Numfor Regency and Loka of Coastal and Marine Resources Management of Sorong-Papua. Our thanks go to Mr. Effendi Igirisa and Mrs. Getreda and friends of the research team from PT. Madani Multi Kreasi Jakarta. Thanks also to the reviewers team who have provided valuable suggestions in improving this manuscript.

\section{References}

Adam, L. 2012. Sustainable fisheries development policy (case study: Wakatobi District, Southeast Sulawesi Province and Morotai Island District, North Maluku Province). Jurnal Perikanan dan Kelautan. 2(2): 115-126.

Cahya, D.L. 2016. Analysis of urban agriculture sustainability in Metropolitan Jakarta (case study: urban agriculture in Duri Kosambi). Procedia - Social and Behavioral Sciences, 227 (2016) : 95 - 100.

Fauzi, A. \& Oxtavianus, A.. 2014. The measurement of sustainable development in Indonesia. J. Ekonomi Pembangunan. 15(1): 68-83.

Gombos, M., Atkinson, S., Green, A. \& Flower, K. (Eds.). 2013. Designing Strong Regional Area Management in Tropical Sea Environment: A Guide for Community-Based Managers, Jakarta,
Indonesia: USAID Coral Triangle Support Partnership.

Herdiansyah, H., Soepandji, B.S., Seda, F.S.S.E. \& Dewi, O. 2014. Conflict Management of Renewable Natural Resources in the Border of Indonesia-Malaysia: Sustainable Environmental Approach. Proc. Environ Sci., 20:444 - 450

Hermantoro, H. 2009. Management of the Maritime Tourism Field in the Implementation of Adaptation Strategies to the Impacts of Climate Change. J. Kepariwisataan Indonesia. 4(1).

Itam, K.O., Etuk, E.A. \& Ukpong, I.G. 2014. Analysis of resource use efficiency among small-scale fish farms in Cross River State, Nigeria. Int. J. Fish. Aquacul. 6 (7):80-86

Leleu, K., Alban, F., Pelletier, D., Charbonel, E., Letourneur, Y. \& Boudouresque. 2012. Fishers' perceptions as indicators of the performance of Marine Protected Areas (MPAs). Marine Policy. 36(2):414-422.

Pitcher. T.J. 1999. Rapfish, A Rapid Appraisal Technique For Fisheries, And Its Application To The Code of Conduct For Responsible Fisheries. FAO Fisheries Circular No. FIRM/C: No. 947: 47pp

Primawaty, E., Basukriadi, A., Syamsu, J.A. \& Soesilo T.E.B. 2013. Sustainability of rice farming based on eco-farming to face food security and climate change: Case study in Jambi Province, Indonesia. Proc. Environ. Sci. 17:53-59

Ratnaningtyas, N.A., Ma'ruf, W.F., Agustini, T.W., Hutabarat, J. \& Anggoro, S. 2016. Prospect and Adversity the Downstream of "Softbone Milkfish" in Semarang City, Indonesia. Aquatic Procedia. 7:66 - 176.

Reuchlin-Hugenholtz, E. \& McKenzie, E. 2015. Marine protected areas: Smart investments in ocean health. WWF, Gland, Switzerland.

Tajerin, Manadiyanto, \& Sastrawidjaja. 2010. The dynamics of marine and fisheries sector linkages in the Indonesian economy, 19952005: Rasmussen's Dual Criterion approach. Jurnal Kebijakan dan Riset Sosek Kelautan dan Perikanan. 5(1):97-112.

Yusvianty. 2010. Sustainable coastal area development planning (case study Pesisir Selatan District) [thesis]. Padang (ID): University of Andalas. 
Yusuf, M.H. 2016. Tallo estuary environmental management model of Makassar urban area [dissertation]. Bogor (ID): Bogor Agricultural University. 